\title{
Suppression of Fusarium oxysporum with recombinant polygalacturonase inhibiting proteins (BvPGIPs) extracted from sugar beet roots
}

\author{
Haiyan $\mathrm{Li}^{1}$ · Ann C. Smigocki ${ }^{1}$
}

Received: 17 May 2018 / Accepted: 26 September 2018 / Published online: 19 October 2018

(c) The Author(s) 2018

\begin{abstract}
Soil-borne fungus Fusarium oxysporum f. sp. betae (Fob) is the causative agent of Fusarium yellows in sugar beet. Leaf interveinal yellowing and root vascular discoloration significantly reduce root yield as well as sucrose content and juice purity. Fob, like other fungal pathogens, initiates disease development by secreting polygalacturonase (PG) enzymes to break down plant cell walls during early stages of infection. To protect themselves, plants produce polygalacturonase-inhibiting proteins (PGIPs). In our study of sugar beet root defense responses, several PGIP genes (BvPGIPs) were identified. To determine if BvPGIPs inhibit Fob PGs, genes BvPGIP1, BvPGIP2 and Bv(FC607)PGIP1 were fused with the CaMV 35S promoter and each was expressed individually in sugar beet hairy roots. We demonstrate that all three recombinant BvPGIP proteins inhibited Fob and F. oxysporum f. sp. gladioli (Fog) PGs. A comparable level of BvPGIP activity was observed against Fob PGs, while BvPGIP2 showed higher activity against Fog PGs. Similar results were obtained when recombinant PGIPs were used to bioassay effects on Fob and Fog spore germination and hyphal growth. This is a first report that documents F. oxysporum inhibition by overexpressing BvPGIPs that may lead to improved Fusarium yellows resistance in sugar beet.
\end{abstract}

Keywords PGIP · Sugar beet root $\cdot$ Fusarium yellows $\cdot$ Fusarium oxysporum

Abbreviations
$\begin{array}{ll}\text { PGIP } & \text { Polygalacturonase-inhibiting protein } \\ \text { PG } & \text { Polygalacturonase } \\ \text { Fob } & \text { Fusarium oxysporum f. sp. betae } \\ \text { Fog } & \text { Fusarium oxysporum } \mathrm{f} \text {. sp. gladioli } \\ B v P G I P & \text { Sugar beet PGIP gene } \\ \text { CaMV 35S } & \text { Cauliflower mosaic virus promotor } \\ \text { LRR } & \text { Leucine-rich repeat } \\ h p t I I & \text { Hygromycin phosphotransferase II } \\ \text { Hyg } & \text { Hygromycin } \\ \text { kb } & \text { Kilobase } \\ \text { PDA } & \text { Potato dextrose agar }\end{array}$

Communicated by Wenwu Guo.

Disclaimer Mention and/or use of a commercial or proprietary product to the exclusion of others does not constitute endorsement by USDA.

Ann C. Smigocki

ann.smigocki@ars.usda.gov

1 Molecular Plant Pathology Laboratory, USDA-ARS, 10300

Baltimore Ave., Beltsville, MD 20705, USA

$\begin{array}{ll}\text { PDB } & \text { Potato dextrose broth } \\ \text { NBT/BCIP } & \begin{array}{l}\text { Nitro blue tetrazolium chloride/5-bromo-4- } \\ \text { chloro-3-indolyl phosphate }\end{array} \\ \text { AP } & \text { Alkaline phosphatase } \\ \text { kDa } & \text { Kilodalton } \\ \text { PVDF } & \text { Polyvinylidene difluoride }\end{array}$

\section{Introduction}

The soil-borne fungus Fusarium oxysporum can cause vascular wilt or root rot on a wide range of plants (Kroes et al. 1998; Olivain and Alabouvette 1999). F. oxysporum $\mathrm{f}$. sp. betae (Fob) is the causative agent of Fusarium yellows disease in sugar beet (Beta vulgaris L.). Fusarium yellows symptoms are characterized by interveinal yellowing on the leaves and vascular discoloration of the root (Hanson and Jacobsen 2009; Harveson 2009). Fusarium yellows significantly reduces root yield as well as sucrose content and juice purity. The disease has been prevalent in western United States for many years and current control measures rely on genetic resistance (Hanson and Jacobsen 2009; Windels et al. 2005). However, resistant cultivars when grown 
in different areas of the country did not provide consistent control to different Fob isolates found in those areas (Hanson et al. 2009, 2018).

In recent years, identifying and applying defense genes for molecular plant breeding has become an effective and environmentally safer approach for improving plant disease resistance. Polygalacturonase-inhibiting proteins (PGIPs) are plant cell wall, leucine-rich repeat (LRR) proteins that have proven to be effective in inhibiting fungal disease development (Kalunke et al. 2015). Using PGIPs for crop protection is considered environmentally safe since they are naturally present in most plants. The role of PGIPs in plant defense has been well documented in heterologous plants but is limited in homologous plants (Gomathi and Gnanamanickam 2004; Kalunke et al. 2015). In rice, over-expression of the endogenous rice $O S P G I P 1$ gene enhanced resistance to sheath blight (Wang et al. 2015; Chen et al. 2016).

Like other plant PGIPs, the sugar beet PGIPs (BvPGIPs) are encoded by gene families and at least two BvPGIPs were isolated from each of the breeding lines F1016, F1010 and FC607 (Li and Smigocki 2016). Over-expressing BvPGIPs in Nicotiana plants increased resistance to fungal pathogens Rhizoctonia solani, F. solani and Botrytis cinerea (Li and Smigocki 2018). The objective of this study was to determine the role of BvPGIPs in resistance to sugar beet pathogens, such as Fob. Since there is still no reliable, rapid method for whole plant regeneration of sugar beet plants from transgenic in vitro cultures, we employed the sugar beet hairy root system as a rapid approach (Smigocki et al. 2009) to obtain transformed sugar beet tissues that express the introduced $B v P G I P$ s. Three highly homologous $B v P$ $G I P$ genes, $B v P G I P 1$ from breeding line F1016, BvPGIP2 from F1010 and F1016 and Bv(FC607)PGIP1 from FC607 (Li and Smigocki 2016, 2018), were engineered for overexpression in F1010 roots with no reported resistance to Fob. Inhibitory activities of the recombinant BvPGIPs were tested against fungal PGs purified from isolates of Fob and F. oxysporum f. sp. gladioli (Fog), a soil-borne fungus that causes Corm rot and yellows in gladiolus (Partridge 2003). The inhibition of Fob and Fog spore germination and hyphal growth by BvPGIPs was also analyzed.

Sugar beet germplasm F1010 (Cambell 1990) was used in this study. F1010 seeds were germinated and grown in a growth chamber at $25^{\circ} \mathrm{C}$ day and $18-20^{\circ} \mathrm{C}$ night temperatures with a day length of $16 \mathrm{~h}$ and $8 \mathrm{~h}$ dark photoperiod. Two Fob isolates, F19 and Fob220a, that are highly virulent on sugar beet, and Fog, not a pathogen of sugar beet, were used in this study (Partridge 2003; Hanson and Hill 2004; Windels et al. 2005; Hanson et al. 2009). All isolates were maintained on potato dextrose agar (PDA) (BD Difco ${ }^{\mathrm{TM}}$, USA).

The BvPGIP1, BvPGIP2 and Bv(FC607)PGIP1 genes were fused to the constitutive CaMV $35 \mathrm{~S}$ promoter and each construct was introduced into a plant transformation vector carrying the $h p t I I$ selectable marker gene, as previously reported (Li and Smigocki 2018). The BvPGIP gene constructs were used to transform F1010 petioles using Agrobacterium rhizogenes-mediated transformation (Smigocki et al. 2009). Roots that regenerated on the petioles were excised and propagated as independent hairy root lines on half-strength B5 medium (PhytoTechnology Laboratories, Overland Park, KS) supplemented with $5 \mathrm{mg}$ Hyg/l to select for hygromycin resistant transformed cells.

$B v P G I P$ gene expression in transgenic hairy roots was analyzed by RT-PCR analysis using gene specific primers (Li and Smigocki 2016). Transcripts of the constitutively expressed actin gene were utilized as an internal control to normalize the RT-PCR results. Gene expression was quantified by densitometry with an AlphaImager HP (Alpha Innotech, San Leandro, CA). RT-PCR analyses were repeated two times with comparable results.

For Southern blot analysis, approximately $10 \mu \mathrm{g}$ of genomic DNA was digested with restriction enzymes $X b a \mathrm{I} /$ Bam HI or NheI (New England BioLabs Inc., Ipswich, MA) that have no recognition sites within the BvPGIP gene sequences, separated on agarose gels and transferred to nylon membranes. Full-length cDNA sequence of each gene was used as a probe. Hybridization signals were detected using alkaline phosphatase and DIG High Prime DNA Labeling and Detection Starter Kit II (Roche, Branchburg, NJ). Membranes were incubated in NBT/BCIP solution (nitro-blue tetrazolium chloride and 5-bromo-4-chloro-3-indolylphosphate $\mathrm{p}$-toluidine salt, 1:50 dilution) (Sigma, St. Louis, MO) for $2 \mathrm{~h}$ at $30^{\circ} \mathrm{C}$ and photographed.

PGIP protein extracts were prepared from $10 \mathrm{~g}$ of hairy root tissues, homogenized in $100 \mathrm{ml}$ of $20 \mathrm{mM} \mathrm{Na}$-acetate buffer containing $1 \mathrm{M} \mathrm{NaCl}(\mathrm{pH} 4.7)$, and purified with Amicon Ultra 15 filtration units (EMD Millipore, Billerica, USA) (Li and Smigocki 2016). Production of PG proteins in Fob and Fog strains was induced with $1 \%$ pectin (Berger et al. 2000). About $10^{5}$ spores harvested with sterile water were inoculated into a flask with $200 \mathrm{ml}$ of potato dextrose broth (PDB), supplemented with $1 \%$ pectin. After a 3-day culture in a rotary shaker at $150 \mathrm{rpm}$, mycelia were removed by centrifugation at $10,000 \times g$ for $10 \mathrm{~min}$. The supernatant was purified and concentrated using Amicon filtration units as described above. Protein concentration was determined using the Bradford method and ND-8000 spectrophotometer (NanoDrop Technologies Inc., DE, USA).

For western blot analysis, concentrated PGIP protein extracts ( $20 \mu \mathrm{g}$ total) were electrophoresed on $12 \%$ TrisGlycine mini gels (XCell SureLock Mini-Cell, Invitrogen, Carlsbad, CA). Separated proteins were transferred to polyvinylidene difluoride (PVDF) membranes using the XCell II Blot Module apparatus (Invitrogen) for $1 \mathrm{~h} 30 \mathrm{~min}$. Membrane blotting and detection of primary antibody were 
carried out using the WesternBreeze Chromogenic Immunodetection Kit (Invitrogen). Briefly, transferred membranes were incubated with rabbit polyclonal antibody against BvPGIP1 peptide (CVQITEAQDIYGPIP) (GenScript Corporation, Piscataway, $\mathrm{NJ}$ ) at 1:2000 dilution for $1 \mathrm{~h}$ and then incubated for $30 \mathrm{~min}$ with alkaline phosphatase conjugated secondary antibody (Goat Anti-Rabbit IgG). Alkaline phosphatase was detected with Chromogenic NBT/BCIP Substrate until purple bands developed on the membrane. The relative levels of the accumulated BvPGIP proteins were estimated by densitometry with an AlphaImager HP.

The inhibitory activity of the extracted BvPGIPs against fungal PGs was determined by agarose diffusion plate assay (Taylor and Secor 1988). BvPGIP activity was determined by calculating the reduction in size of the halo produced when one unit of PG was reacted with $15 \mu \mathrm{g}$ of PGIPs isolated from the transgenic hairy lines as compared to the halo produced by the empty vector control line. One PG unit represents a halo of $5 \mathrm{~mm}$ radius produced after overnight incubation at $30{ }^{\circ} \mathrm{C}$ with $0.5 \%$ polygalacturonic acid substrate (Sigma, St. Louis, MO). Inactivated PGIPs (boiled at $100{ }^{\circ} \mathrm{C}$ for $5 \mathrm{~min}$ ) mixed with F19 PG were included as a negative control. Each assay was conducted in triplicate and repeated two times. The size of halo is presented as mean \pm standard deviation (SD) (Microsoft Excel program).

To test the inhibitory activity of recombinant BvPGIP on fungal spore germination, $10^{3}$ spores harvested in sterile water were added to $15 \mu \mathrm{g}$ of PGIP protein extract $(20 \mu \mathrm{l}$ total volume). The spore-PGIP mix was incubated at $30{ }^{\circ} \mathrm{C}$ in the dark for $0,3,24$ and $48 \mathrm{~h}$ and then plated on PDA media for $24 \mathrm{~h}$. Spore germination frequency from each incubation time point was photographed with a Zeiss SteREO Discovery microscope $(\times 20)$ (Zeiss, SteREO Discovery, San Diego, CA). Spores that were treated with PGIP extracts for $24 \mathrm{~h}$ were used to determine PGIP activity on hyphal growth at $48 \mathrm{~h}$ after plating spores on PDA media. The recombinant BvPGIP activity was determined by the percentage of reduction of colony size relative to fungal growth of spores treated with PGIP extracts from hairy roots transformed with the empty vector that represents the background level of PGIP activity. Each experiment was repeated two times. Size of colony is presented as mean $\pm \mathrm{SD}$ (Microsoft Excel program).

In this study, three genes that encode BvPGIP1, BvPGIP2 and $\mathrm{Bv}$ (FC607)PGIP1 were fused to the constitutive CaMV $35 \mathrm{~S}$ promoter and were over-expressed separately in hairy roots of the sugar beet breeding line, F1010. At least three independently derived hairy root lines were regenerated from each $B v P G I P$ transformed F1010 petioles. Southern blot analysis of BvPGIPI (3-1 and 3-3), BvPGIP2 (7-2 and 7-3) and $B v(F C 607) P G I P 1$ (1-3 and 1-5) hairy root lines revealed that 1-2 copies of each $B v P G I P$ gene were integrated into F1010 genome (Fig. 1a). Since the sequences of $B v P G I P 1, B v P G I P 2$ and $B v(F C 607) P G I P 1$ are $97-98 \%$ identical, cross-hybridization is highly likely between the introduced transgene and the endogenous BvPGIP2 gene found in the F1010 background ( $\mathrm{Li}$ and Smigocki 2016). The single hybridization signal generated with the NheI restriction enzyme in line BvPGIP1 3-1 likely represents two similar or identical size bands since two distinct size bands were detected when the DNA was digested with

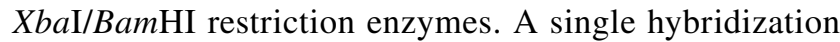
band was detected in all empty vector control lines (C).

RT-PCR analysis revealed elevated $B v P G I P$ transcript levels in all transgenic $B v P G I P 1, B v P G I P 2$ and $B v(F C 607)$ $P G I P 1$ lines (Fig. 1b). Relatively higher $B v P G I P 2$ transcript levels were observed in lines 7-2 and 7-3 as compared to the control (C) that, as expected, showed low endogenous transcript levels in the F1010 background. No PGIP transcripts or very weak bands were detected in the BvPGIPl or Bv(FC607)PGIP1 controls.

Western blot analysis using BvPGIP specific polyclonal antibody confirmed the presence of the recombinant PGIP proteins in transgenic hairy root lines (Fig. 1c). Proteins of about $42 \mathrm{kDa}$ cross-reacted with the BvPGIP antibody in all samples tested, with consistently higher levels of PGIP proteins observed in the transgenic BvPGIP lines as compared to the controls. The two weak bands in the BvPGIPI and $B v(F C 607) P G I P 1$ control lines could be non-specific because these two genes were highly homologous with the endogenous $B v P G I P 2$ gene in the controls. A weaker protein band corresponding to $36-40 \mathrm{kDa}$ was observed in BvPGIPI lines 3-1 and 3-3 and may represent a modified or partially degraded form of the $42 \mathrm{kDa}$ PGIP protein, or some nonspecific bands.

The activity of the recombinant BvPGIP proteins for Fob and Fog PGs was demonstrated using agarose diffusion assays (Fig. 2a, b). Protein extracts prepared from $B v P G I P I$ (3-1, 3-3), BvPGIP2 (7-2, 7-3) and Bv (FC607)PGIP1 (1-3, 1-5) lines inhibited the Fob and Fog PGs. Highest PGIP activity was observed against Fog PGs (45-87\% reduction of halo) followed by Fob isolate F19 at 31-46\% and Fob220a at $28-42 \%$ reduction, as compared to the activities of the endogenous BvPGIP2 in the empty vector control line (Fig. 2b). The higher activity against Fog PGs may be associated with the fact that Fog is not a pathogen of sugar beet and thus would be less likely to develop resistance to sugar beet PGIPs. BvPGIP1, BvPGIP2 and Bv(FC607)PGIP1 activities against Fob F19 or Fob220a PGs were similar, i.e. a reduction of the halo by $28-46 \%$ (Fig. $2 b$ ). However, BvPGIP2 protein extracts (line 7-2, 7-3) showed higher activity (80-87\% reduction of halo) for Fog PGs than the BvPGIP1 and Bv(FC607)PGIP1 extracts (45-55\% reduction). No inhibition of F19 PGs was observed when PGIP extracts were heat inactivated prior to mixing with the PGs (last row; Fig. 2a). 
Fig. $1 \quad B v P G I P$ gene expression in transformed sugar beet hairy roots. a Southern blot analysis of independently derived hairy root lines of BvPGIP1 (3-1, 3-3), BvPGIP2 (7-2, 7-3) and $B v(F C 607) P G I P 1$ (1-3, 1-5).

Genomic DNA $(10 \mu \mathrm{g})$ was digested with three restriction enzymes (XbaI, BamHI and NheI) that do not cut within $B v P G I P s$ and probed with the full-length cDNA fragment of each gene. $\mathrm{C}$ represents the control hairy roots transformed with the empty vector that has no $P G I P$ gene inserted in the vector. $\mathbf{b} B v P G I P$ transcription in hairy root lines. RT-PCR was performed with total RNA using gene-specific primers that amplify about $1.0 \mathrm{~kb}$ of the coding region of each transgene. The sugar beet actin gene was used as an internal control. c Detection of recombinant BvPGIP proteins in hairy root lines. Western blot analysis was performed by separating PGIP proteins $(20 \mu \mathrm{g})$ on $12 \%$ Tris-Glycine gels that were then transferred to PVDF membranes. Membranes were incubated with anti-BvPGIP1 antibody followed by alkaline phosphatase (AP) conjugated secondary antibody (Goat antiRabbit IgG)

\section{A}
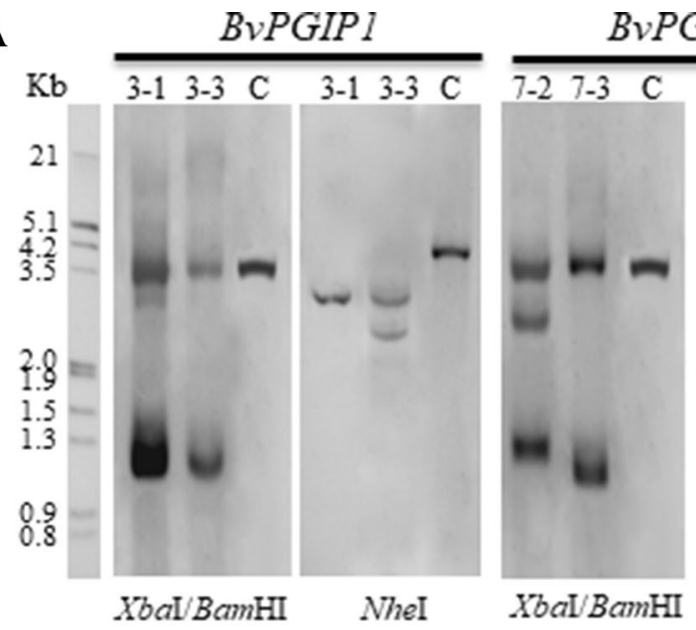

Xbal/BamHI

\section{GIP2}

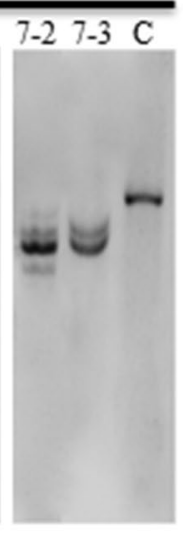

NheI

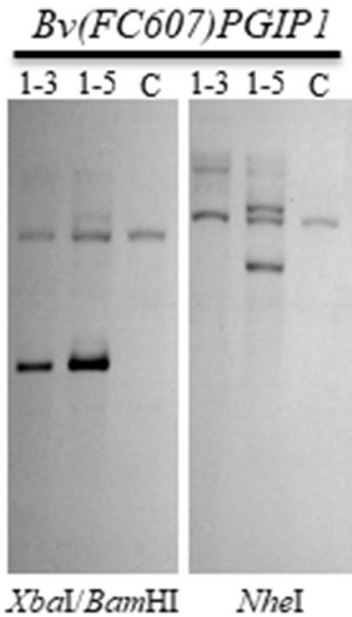

B

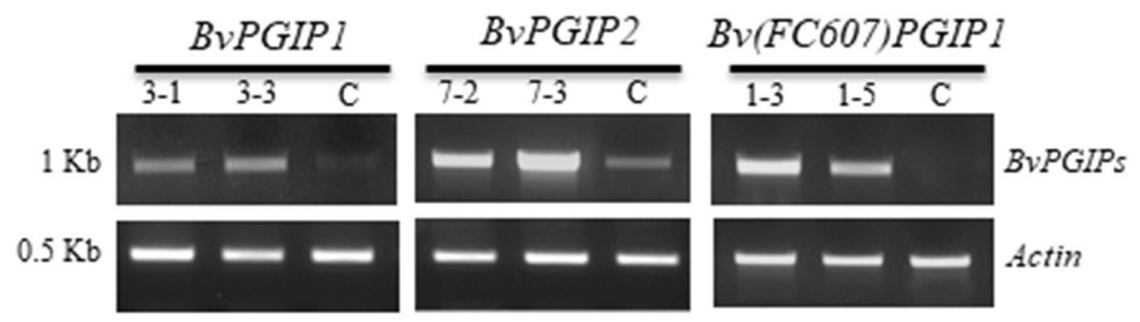

C

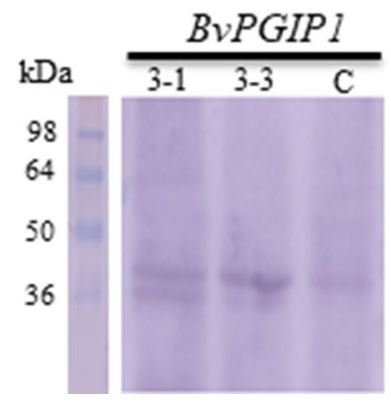

$B v P G I P 2$

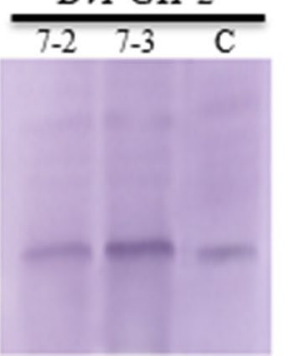

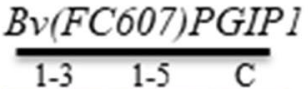

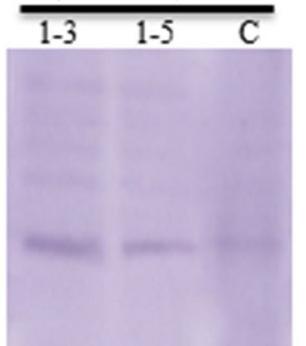

Recombinant BvPGIP protein extracts were also tested for their effect on fungal spore germination. When BvPGIP1 3-1 protein extract was mixed with Fog spores, a large reduction in the number of germinated spores was observed at 3 and $24 \mathrm{~h}$ after incubation (Fig. 3a, a 2 and a3, respectively). An almost complete inhibition of spore germination was observed after 48 h (Fig. 3a, a4). Replacing PGIP extract with water or heat denatured protein extract had no effect on Fog spore germination (data not shown; Fig. 3a, a5, respectively).

Viability of Fob and Fog spores was determined after they were treated with each of the three PGIP extracts for $24 \mathrm{~h}$. A significant reduction of fungal growth was observed for all spores treated with the PGIP extracts (Fig. 3b, c). Fog colony sizes were reduced by $40-80 \%$ when they were treated with one of the three extracts, followed by $40-62 \%$ reduction of
F19 and 27-41\% reduction of Fob220 colonies. As observed with the Fog PG extracts (Fig. 2), the Fog isolate was most strongly inhibited by the BvPGIP2 extract showing a 70-80\% colony size reduction, followed by BvPGIP1 with $55-60 \%$ and $\mathrm{Bv}(\mathrm{FC} 607) \mathrm{PGIP} 1$ with $40-44 \%$ reduction. The vector control extracts showed a 17,24 , and $33 \%$ reduced colony sizes for F19, Fob220a and Fog, respectively as compared to PG control with no PGIP extract added.

Because $B v P G I P 2$ is the endogenous gene found in the F1010 genome that was used for the transformation experiments and as the vector control, we conclude that overexpressing BvPGIP2 in F1010 hairy root lines 7-2 and 7-3 did not trigger the onset of gene co-suppression which would lead to reduced $B v P G I P 2$ gene activity. We speculate that the enhanced activity of the BvPGIP2 protein extracts against Fog PGs may be due in part to the eight amino acid 


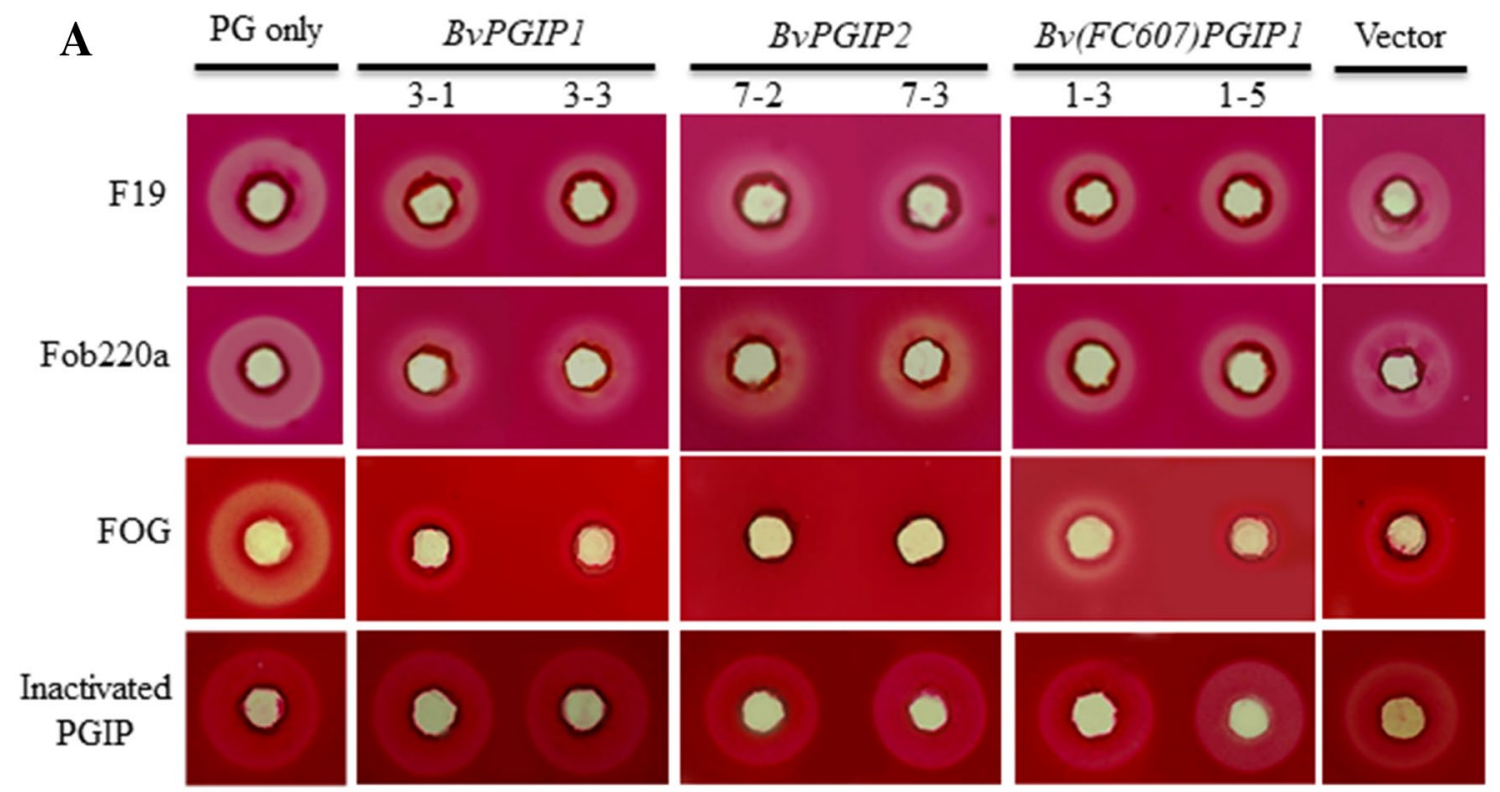

B

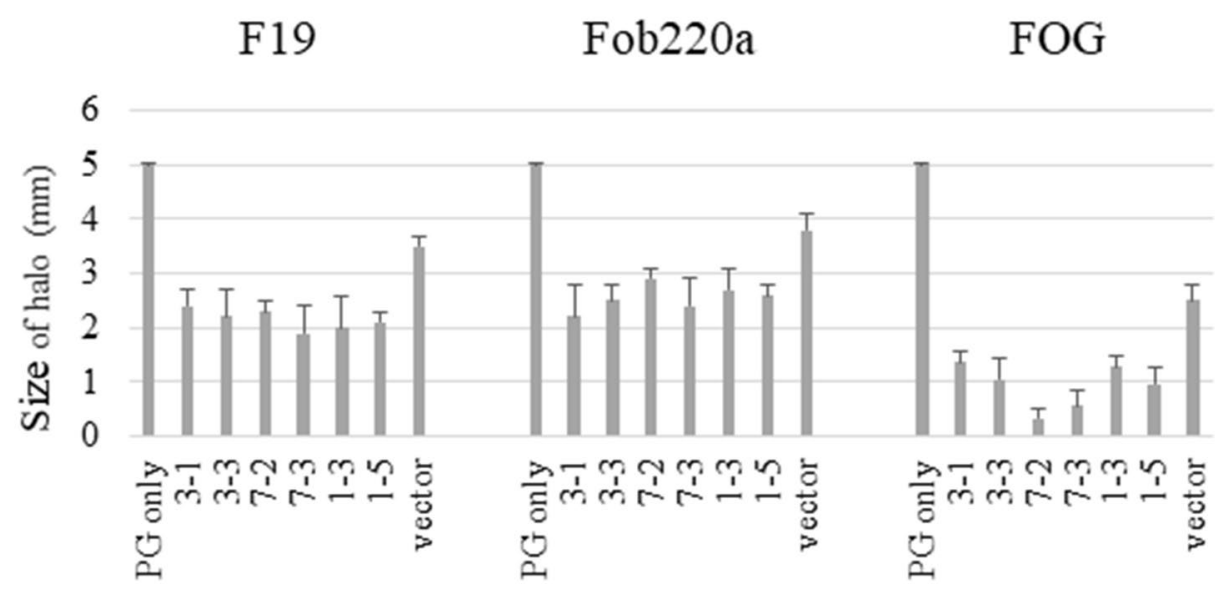

Fig. 2 BvPGIP inhibition of fungal PGs. a Agarose diffusion assays showing PGIP inhibition of fungal PGs. PGIP extracts $(15 \mu \mathrm{g})$ from BvPGIP1 (3-1, 3-3), BvPGIP2 (7-2, 7-3) and Bv(FC607)PGIP1 (1-3, 1-5) lines were each mixed with one unit of fungal $P G$ from isolates Fob F19, Fob220a and Fog. PG only represents one unit of PG that produces a halo of $5 \mathrm{~mm}$ radius after overnight incubation at $30^{\circ} \mathrm{C}$.

substitutions found between BvPGIP1 and BvPGIP2 (Li and Smigocki 2016). Of the eight amino acids, four (T/A, G/R, M/I, N/D) are located within the xxLxLxx motif, where the PGIP-PG recognition occurs (Desiderio et al. 1997). Therefore, the stronger recognition capacity between BvPGIP2 and Fog PGs most likely may involve one or more of these four amino acids.

In conclusion, this is a first report documenting the inhibitory activity of sugar beet PGIPs on Fog and Fob pathogens, causative agents of Corm rot and yellows in gladiolus and
Heat inactivated PGIP extracts $\left(100{ }^{\circ} \mathrm{C}\right.$ for $\left.5 \mathrm{~min}\right)$ were mixed with F19 PG as negative controls. b Comparison of halo sizes that represent the inhibitory activity of BvPGIPs against PGs of F19, Fob220a and Fog. Smaller halo indicates higher PGIP activity. Values are given as mean \pm standard deviation $(\mathrm{SD})$

Fusarium yellows in sugar beet, respectively. The recombinant BvPGIP1, BvPGIP2 and Bv(FC607)PGIP1 proteins over-expressed in sugar beet hairy roots inhibited Fog and Fob PGs, spore germination and hyphal growth, showing highest activity against Fog PGs. All three BvPGIP extracts showed similar level of activity against Fob F19 and Fob220a, while BvPGIP2 showed higher inhibition of Fog. Reports of PGIP inhibition of $F$. oxysporum PGs are limited. Only one study has shown that the activity of PGs isolated from $F$. oxysporum f.sp. lycopersici was partially inhibited 


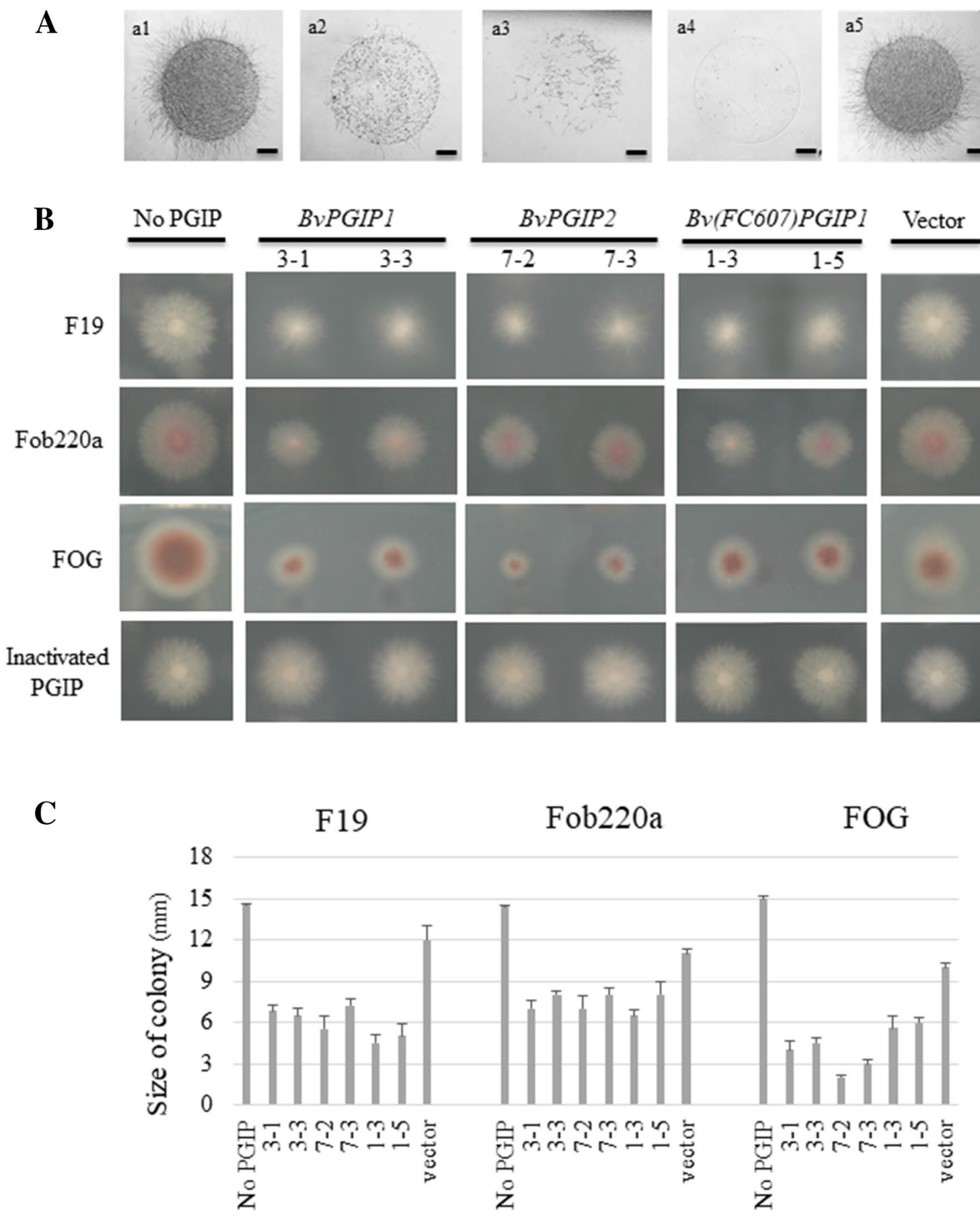

Fig. 3 BvPGIP inhibition of fungal growth. a Inhibition of spore germination. a1 No PGIP extract added to Fog spores. a2-a4 Fog spores were mixed with $B v P G I P 1$ 3-1 PGIP extract and incubated at $30{ }^{\circ} \mathrm{C}$ in the dark for $3 \mathrm{~h}, 24 \mathrm{~h}$, and $48 \mathrm{~h}$, respectively. a5 Fog spores were incubated with heat inactivated PGIP extracts for $24 \mathrm{~h}$. Photos were taken with a Zeiss SteREO Discovery microscope $(\times 20)$ at $24 \mathrm{~h}$ after plating the PGIP-spore mix on PDA media. Bar $=1 \mathrm{~mm}$. b Hyphal growth from F19, Fob220a and Fog spores treated with BvPGIP1
(3-1, 3-3), BvPGIP2 (7-2, 7-3) and Bv(FC607)PGIP1 (1-3, 1-5) extracts. No PGIP refers to spores not treated with recombinant PGIP extract. Heat inactivated PGIP extracts were mixed with F19 spores as negative controls. c Comparison of colony sizes that represent the inhibitory activities of recombinant PGIPs against growth of F19, Fob220a and Fog. Smaller size of colony indicates higher PGIP activity. Values are given as mean \pm standard deviation (SD) 
by the bean PvPGIP1, however, PvPGIP1 over-expression in tomato did not increase fungal resistance (Desiderio et al. 1997). Our findings demonstrate a relatively broad inhibitory capacity of recombinant sugar beet BvPGIPs against three different $F$. oxysporum isolates using transgenic sugar beet root lines. In addition, this study provides the basis for gaining a better understanding of the molecular mechanisms of sugar beet and $F$. oxysporum interaction and opens new strategies for controlling fungal diseases in sugar beet and other crops.

Acknowledgements We thank Dr. L. Hanson (USDA-ARS, Sugarbeet and Bean Research Unit, East Lansing, MI) for providing the Fob isolates, and Dr. D. Lakshman (USDA-ARS, Beltsville, MD) for the Fog isolate.

Author contributions HL and ACS designed the experiments; HL performed the experiments, analyzed the data and wrote the manuscript; ACS conceived and directed the research, analyzed and interpreted the data and wrote and edited the manuscript.

Funding This project is in part supported by a Cooperative Agreement No. 58-1245-4-002N between the U.S. Department of Agriculture and the Beet Sugar Development Foundation.

\section{Compliance with ethical standards}

Conflict of interest The authors declare that there is no conflict of interest regarding the publication of this paper.

Open Access This article is distributed under the terms of the Creative Commons Attribution 4.0 International License (http://creativeco mmons.org/licenses/by/4.0/), which permits unrestricted use, distribution, and reproduction in any medium, provided you give appropriate credit to the original author(s) and the source, provide a link to the Creative Commons license, and indicate if changes were made.

\section{References}

Berger DK, Oelofse D, Arendse MS, Plessis ED, Dubery IA (2000) Bean polygalacturonase inhibitor protein-1 (PGIP-1) inhibits polygalacturonases from Stenocarpella maydis. Physiol Mol Plant Pathol 57:5-14

Cambell LG (1990) Registration of F1010 sugarbeet germplasm. Crop Sci 30:429-430

Chen XJ, Chen Y, Zhang LN, Xu B, Zhang JH, Chen ZX, Tong YH, Zuo SM, Xu JY (2016) Overexpression of OsPGIP1 enhances rice resistance to sheath blight. Plant Dis 100:388-395
Desiderio B, Aracri F, Leckie B, Mattei G, Salvi H, Tigelaar JS, Van Roekel DC, Baulcombe LS, Melchers G, De Lorenzo G (1997) Polygalacturonase-inhibiting proteins (PGIPs) with different specificities are expressed in Phaseolus vulgaris. Mol Plant Microbe Interact 10:852-860

Gomathi V, Gnanamanickam SS (2004) Polygalacturonase-inhibiting proteins in plant defence. Curr Sci 87:1211-1217

Hanson LE, Hill AL (2004) Fusarium species causing Fusarium yellows of sugarbeet. J Sugar Beet Res 41:163-178

Hanson LE, Jacobsen BJ (2009) Fusarium yellows. In: Compendium of beet diseases and pests. APS Press, Washington, DC, pp 28-29

Hanson LE, Hill AL, Jacobsen BJ, Panella L (2009) Response of sugarbeet lines to isolates of Fusarium oxysporum f. sp. betae from the United States. J Sugar Beet Res 46:11-26

Hanson LE, De Lucchi C, Stevanato P, McGrath M, Panella L, Sella L, De Biaggi M, Concheri G (2018) Root rot symptoms in sugar beet lines caused by Fusarium oxysporum f. sp. betae. Eur J Plant Pathol 150:589-593

Harveson RM (2009) Fusarium root rot. In: Compendium of beet diseases and pests. APS Press, Washington, DC, pp 30-31

Kalunke RM, Tundo S, Benedetti M, Cervone F, De Lorenzo G, D'Ovidio R (2015) An update on polygalacturonase-inhibiting protein (PGIP), a leucine-rich repeat protein that protects crop plants against pathogens. Front Plant Sci 6:146

Kroes GMLW, Baayen RP, Lange W (1998) Histology of root rot of flax seedlings (Linum usitatissimum) infected by Fusarium oxysporum f. sp. lini. Eur J Plant Pathol 104:725-736

Li H, Smigocki AC (2016) Wound induced Beta vulgaris polygalacturonase-inhibiting protein genes encode a longer leucine-rich repeat domain and inhibit fungal polygalacturonases. Physiol Mol Plant Pathol 96:8-18

Li H, Smigocki AC (2018) Sugar beet polygalacturonase-inhibiting proteins with 11 LRRs confer Rhizoctonia, Fusarium and Botrytis resistance in Nicotiana plants. Physiol Mol Plant Pathol 102:200-208

Olivain C, Alabouvette C (1999) Process of tomato root colonization by a pathogenic strain of Fusarium oxysporum f. sp. lycopersici in comparison with a non-pathogenic strain. New Phytol 141:497-510

Partridge JE (2003) Fusarium rot and yellows of Gladiolus. University of Nebraska, Lincoln, p 47

Smigocki AC, Puthoff DP, Zuzga S, Ivic-Haymes SD (2009) Low efficiency processing of an insecticidal Nicotiana proteinase inhibitor precursor in Beta vulgaris hairy roots. Plant Cell Tissue Organ Cult 97:167-174

Taylor RJ, Secor GA (1988) An improved diffusion assay for quantifying the polygalacturonase content of Erwinia culture filtrates. Phytopathology 78:1101-1103

Wang R, Lu L, Pan X, Hu Z, Ling F, Yan Y, Liu Y, Lin Y (2015) Functional analysis of $O S P G I P 1$ in rice sheath blight resistance. Plant Mol Biol 87:181-191

Windels CE, Brantner JR, Bradley CA, Khan MFR (2005) First report of Fusarium oxysporum causing yellows on sugar beet in the Red River Valley of Minnesota and North Dakota. Plant Dis 89:341 